\title{
Simulasi Pemograman Pengendali PWM Kecepatan dengan Mikrokontroler Arduino berbasis Sensor Ultrasonik HC-SR04 pada Purwarupa Mobil Listrik
}

\author{
Dwi Aji Saputra ${ }^{1}$, Bana Handaga ${ }^{2}$, Marwan Effendy ${ }^{3}$, Dimas Ardiansyah Halim ${ }^{4}$ \\ ${ }^{1,4}$ Program Studi D III Teknik Mesin, Akademi Teknik Wacana Manunggal Semarang \\ ${ }^{2}$ Program Studi Teknik Informatika, Universitas Muhammadiyah Surakarta \\ ${ }^{3}$ Program Studi Teknik Mesin, Universitas Muhammadiyah Surakarta \\ Email: 1dasfotograph@yahoo.co.id, ${ }^{2}$ bana.handaga@ums.ac.id, ${ }^{3}$ marwan.effendy@ums.ac.id, \\ ${ }^{4}$ dimasardiansyah@atwm.ac.id
}

\begin{abstract}
ABSTRAK
Proses pengereman menjadi dasar pembuatan sistem pengendali PWM kecepatan agar mobil listrik dapat berhenti secara otomatis serta meningkatkan keselamatan dalam berkendara. Penggunaan motor listrik sebagai penggerak roda mobil listrik memungkinkan pengendalian dengan mikrokontroler. Berdasarkan jurnal tentang pengendalian motor listrik maka perlu diteliti penggunaan PWM sebagai pengendali kecepatan motor listrik. Bahasa C sebagai bahasa coding dapat dimengerti oleh mikrokontroler Arduino dengan tujuan untuk mengatur kecepatan motor listrik. Tujuan penelitian yaitu menggunakan pemrograman bahasa C sebagai pengendali PWM kecepatan dengan mikrokontroler Arduino. Metodologi yang digunakan dalam penelitian ini memodifikasi mobil remote control (RC) dibuat sebagai purwarupa mobil listrik. Sistem mikrokontroler Arduino dipasang dan diprogram dengan bahasa C sebagai pengendali PWM kecepatan. Alat sensor utama yang dipergunakan yaitu sensor jarak ultrasonik sebagai data input mikrokontroler. Motor arus searah (DC) pada mobil RC diatur dengan sinyal pulse width modulation (PWM) sebagai luaran dari Arduino. LCD dan buzzer digunakan sebagai alat penampil dan indikator jarak aman antara purwarupa dan penghalang. Hasil pengujian mendapatkan hasil jarak deteksi sensor ultrasonik mencapai $2 \mathrm{~cm}$ sampai 500 meter. Kemudian data percepatan diperoleh pulse width modulation 64 jarak 1 meter, 127 jarak 3 meter, 191 jarak 4 meter, 225 jarak 5 meter serta dibuat dalam bentuk grafik. Pada sistem pengendalian kecepatan, penggunaan mikrokontroler Arduino UNO mudah dalam pengaplikasian serta memiliki fitur yang lengkap. Rangkaian sistem pengendali kecepatan dapat diaplikasikan pada mobil listrik dengan kriteria penurunan PWM secara perlahan dalam dua tahap. Proses penurunan PWM membutuhkan waktu 1 detik setelah sensor mendeteksi objek penghalang.
\end{abstract}

Kata-kata kunci: Pengendali Kecepatan, Pwm, Motor DC, Arduino, Sensor Jarak Ultrasonik.

\section{ABSTRACT}

The braking process is the basis in the making of the PWM speed control system in order for electric cars to be able to stop automatically and increase the driving safety. The usage of an electric motor as a wheel drive for an electric car allows controlling with a microcontroller. Based on the journal about electric motor control, it is necessary to study the use of PWM as a speed controller. The $C$ language as a coding language can be understood by the Arduino microcontroller with the aim of regulating the speed of the electric motor. The research objective was to use the $C$ language programming as a PWM speed controller with the Arduino microcontroller. The methodology used in this study was to modify a remote control car $(R C)$ made as a prototype electric car. The Arduino microcontroller system was installed and programmed in C language as a PWM speed controller. The main sensor tool used was the ultrasonic distance sensor as the microcontroller input data. Direct current (DC) motors on RC cars were regulated with a pulse width modulation (PWM) signal as the output from the Arduino. LCD and buzzer were used as display devices and indicators of safe distances between prototypes and obstructions. The test results showed that the detection distance of the ultrasonic sensor reached $2 \mathrm{~cm}$ to 500 meters. Then the acceleration data obtained by pulse width modulation 64 at 1 meter distance, 127 at 3 meter distance, 191 at 4 meter distance, 225 at 5 meter distance and was made in graphic form. In a speed control system, the usage of the Arduino UNO microcontroller was easy to apply and had complete features. The 
series of speed control systems could be applied to electric cars with the PWM slow reduction criteria in two stages. The $P W M$ lowering process took 1 second after the sensor detects an obstruction object.

Keywords: Speed controller, PWM, DC motor, Arduino, ultrasonic proximity sensor.

\section{Pendahuluan}

Mobil listrik dimata dunia sedang menjadi perhatian utama karena menggunakan energi listrik dari aki sebagai sumber tenaga. Mobil listrik mengeluarkan gas buang yang minim sehingga dapat menjadi salah satu solusi masalah polusi udara. Kendaraan yang memiliki predikat "zero emission" ini menjadi alternatif solusi mengurangi kadar $\mathrm{CO}_{2}$ dan gas kimia yang menjadi keluaran dari alat transportasi sehingga diharapkan dapat menurunkan global warming [1].

Sistem pengereman yang digunakan pada mobil listrik saat ini masih belum bisa dikatakan safety. Pemutusan energi listrik tidak serta merta membuat mobil berhenti seketika. Sistem pengereman juga belum sesuai untuk mendukung mobil listrik yang bisa kencang serta nyaman. Sistem pengereman mobil listrik masih menggunakan sistem manual dengan regeneratif. Sistem ini mengkonversi energi mekanis dari gaya gesek menjadi bentuk energi yang dapat disimpan pada baterai mobil listrik sehingga dapat digunakan kembali saat diperlukan [2].

Tingkat keamanan dalam berkendara menjadi salah satu prioritas dalam menggunakan sarana transportasi. Begitu pula pada mobil listrik, selain peningkatan pada kapasitas baterai dan laju maksimum, tentu sistem pengereman yang mendukung tingkat keamanan berkendara sangat diperlukan. Ketika mobil melaju kencang diperlukan jarak pengereman tertentu untuk membuat sebuah mobil berhenti total. Braking distance atau jarak pengereman ini berbanding lurus dengan kecepatan mobil [3].

Sistem pengendali kecepatan di pasaran masih banyak menggunakan AVR Atmega. Dimana Atmega yang berbentuk chip ini memerlukan sistem tambahan lain untuk mendukung hapus-tulis program, bagian memori dan board[4]. Pada perkembangan pengendali kecepatan, mikrokontroler Arduino telah diramu dalam bentuk satu board khusus sehingga pengguna dapat langsung memasukkan bahasa program dan setiap input maupun outputnya dapat dihubungkan. Pengaturan kecepatan motor listrik DC dilakukan dengan sinyal PWM. Mikrokontroler Atmega8535 telah digunakan dalam pengujian sistem pengaturan kecepatan dengan sinyal PWM [5][6].

Pemilihan dan penggunaan metode PWM dikarenakan metode PWM memiliki kemampuan untuk mengolah kecepatan motor serta mencegah pemakaian daya berlebih pada rangkaian elektronik[7]. Tegangan yang disuplai pada rangkaian pada interval waktu tertentu itulah alasan PWM dapat mengolah kecepatan motor.[8]

Sensor ultrasonik tipe ping telah dimanfaatkan untuk referensi safety system pada mobil listrik. Sensor ultrasonik dapat digunakan sebagai ukuran tegangan sebagai input motor DC pada sistem mekanisasi pengendali motor DC. Metode dinamis dan metode plugging dipakai dalam mekanisme pengereman. Dimana pengereman metode dinamis mengubah motor listrik sehingga berperan sebagai generator. Gaya gerak listrik yang dibangkitkan pada belitan jangkar diberi beban oleh resistor sehingga energi pengereman tereliminasi pada resistor tersebut dalam bentuk panas. Pengereman metode plugging yaitu dengan cara reversi polaritas tegangan pada jangkar atau pada penguat medan. Dengan metode plugging tersebut motor listrik dapat lebih cepat berhenti berputar dan memiliki kecenderungan berbalik arah [9].

Kecepatan motor dan tegangan terminal memiliki hubungan berbanding lurus. Hal ini memiliki maksud semakin rendah tegangan maka kecepatan motor juga semakin lambat. Nilai lebih dalam mengatur kecepatan motor DC dengan metode PWM yaitu mudah, tidak ribet dan ekonomis dalam implementasinya [10].

Penelitian dengan metode action research memiliki tujuan mengelaborasi suatu pendekatan baru dalam menyelesaikan masalah dengan aplikasi langsung di dunia nyata[11]. Metode action research inilah yang digunakan pada penelitian ini.

Mikrokontroler Arduino UNO serta HC-SR04 sensor ultrasonik digunakan dalam penelitian ini sebagai alat kontrol utama. Perancangan sebuah purwarupa pengatur kecepatan otomatis untuk mobil listrik dengan simulasi pada mobil RC. Proses yang diasumsikan berupa pedal rem dikarenakan mobil RC mempunyai karakteristik 
penggerak elektronik yang sama. Ide perancangan pengatur kecepatan otomatis yaitu apabila mobil RC melaju pada kecepatan tertentu dan pada posisi yang telah ditentukan diberi sebuah penghalang, maka mikrokontroler dan PWM akan mereduksi kecepatan mobil RC secara otomatis serta bertahap. Pengendalian pedal rem tersebut sampai kemudian mobil RC berhenti saat jarak dengan penghalang semakin dekat.

\section{Metodologi Penelitian}

\subsection{Tahap pembuatan purwarupa berupa} mobil Remote Control (RC)

a. Persiapan komponen elektronik dan material rangka serta badan purwarupa mobil RC.

b. Pembuatan desain PCB yang menggunakan bantuan perangkat lunak Proteus 7.91.

c. Pengerjaan sablon PCB.

d. Proses pelarutan PCB.

e. Penyambungan sistem elektronik dan rangkaian driver motor pada PCB dengan solder.

f. Pembuatan desain serta proses pemotongan rangka mobil RC.

g. Pembuatan desain dan proses pemasangan gear box mobil RC.

h. Perakitan dan pemasangan posisi Arduino, PCB, sensor ultrasonik, roda serta kabel penghubung sampai tahap jadi.

Proses selanjutnya yaitu mensimulasikan sistem pengendali kecepatan otomatis pada mobil RC. Setelah itu, dilanjutkan pembuatan data dengan dasar Bahasa C. Skema sistem pengendali kecepatan otomatis ditampilkan pada gambar 4 .

Sensor ultrasonik menangkap data jarak mobil dengan objek penghalang. Kemudian data diteruskan ke mikrokontroler Arduino, selanjutnya output dari Arduino berupa sinyal tegangan PWM. Sinyal PWM tersebut dilanjutkan pada rangkaian driver L293D yang akan menjadi dasar penggerak motor DC. Di lain pihak, apabila jarak yang disuplai memnuhi nilai atau kriteria pengaturan tertentu maka Arduino akan memasok sinyal pada lampu LED, buzzer, dan LCD. Dimana lampu LED akan berkedip-kedip dan LCD menampilkan data jarak yang telah ditangkap.

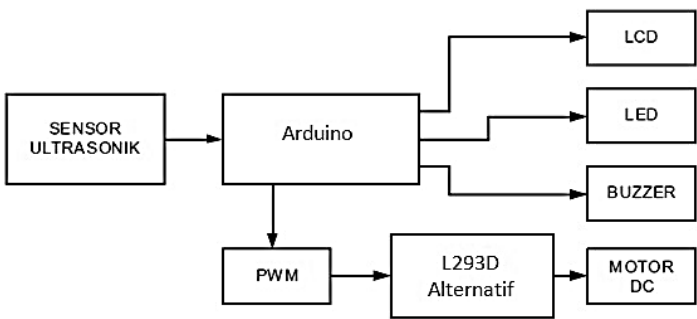

Gambar 4. Skema sistem pengendali kecepatan otomatis

\subsection{Alat dan Bahan}

Bahan meliputi :

a. Mur Baut

b. Kabel untuk komponen komponen PCB

c. Dioda

d. Solder

e. Timah

f. Bahan chasis

g. Soket

h. Push bottom

i. Baterai Lippo

Alat meliputi :
a. Obeng
b. Tang potong
c. Solder
d. Alat pemotong bahan body

Purwarupa meliputi :

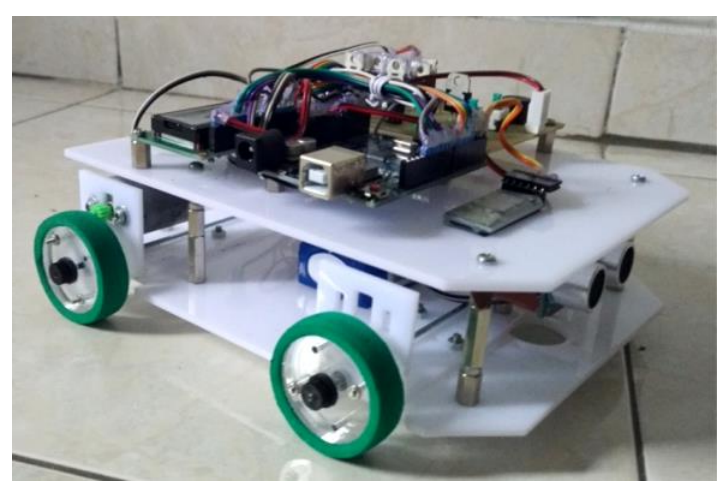

Gambar 5. Purwarupa simulasi pengendali kecepatan otomatis mobil RC.

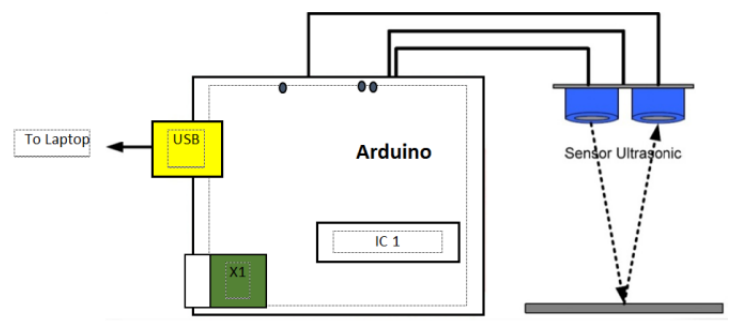

Gambar 6. Skema sinkron pemrograman "Bahasa C" 
Setelah purwarupa mobil RC siap digunakan, kegiatan yang dilakukan yaitu penulisan program "Bahasa C". Pemrograman "Bahasa C" dilakukan dalam beberapa tahapan trial and error sehingga dapat memenuhi kriteria pengendalian kecepatan otomatis. Ketika program sudah memnuhi kriteria, maka tahap pengambilan data dilakukan dengan cara mencatat data percepatan PWM serta jarak objek penghalang. Data tersebut kemudian diolah dan ditampilkan nerupa tabel dengan bantuan perangkat lunak Excel. Luaran dari excel yaitu dimunculkan grafik hubungan variasi kecepatan motor PWM dan jarak objek penghalang sampai kondisi berhenti.

\section{Hasil dan Pembahasan}

Proses memperoleh data jarak antara sensor dan objek penghalang dilakukan dengan memposisikan purwarupa di ruang terbuka. Kemudian meletakkan purwarupa dengan jarak tertentu dari objek penghalang dan pembacaan jarak oleh sensor ultrasonik akan tertampil. Pada pengukuran pertama, purwarupa diletakkan sejauh $100 \mathrm{~cm}$ dari objek penghalang. Pada pembacaan sensor ultrasonik menunjukkan jarak $98 \mathrm{~cm}$. Pengukuran kedua yaitu jarak objek penghalang pada $300 \mathrm{~cm}$, terbaca oleh sensor sejauh $295 \mathrm{~cm}$. Pada pengambilan data ketiga jarak purwarupa 400 cm dan tampilan data pada sensor yaitu $396 \mathrm{~cm}$. Kemudian pengambilan data keempat pada jarak $500 \mathrm{~cm}$, sensor ultrasonik menampilkan jarak 496 $\mathrm{cm}$. Penggambaran pengukuran data jarak purwarupa dan objek penghalang ditampilkan pada gambar 7 sedangkan tabel 1 menunjukkan grafik perbandingan jarak yang diukur dengan meteran dan sensor ultrasonik.

Berdasarkan pengambilan data diperoleh hasil yaitu sensor ultrasonik HC-SR04 dapat menaksir jarak dengan rentang antara $100 \mathrm{~cm}$ sampai 500 $\mathrm{cm}$. Hasil taksiran jarak dari sensor ultrasonik dengan alat meteran memiliki perbedaan $2-5 \mathrm{~cm}$. Menurut hasil penelitian Zulmi [12] pada tahun 2014 kesalahan pengukuran jarak dari sensor ultrasonik yaitu sekitar $1 \mathrm{~cm}$ bila dibandingkan dengan pengukuran mistar. Pada pengambilan data yang telah dilakukan, kesalahan yang terjadi lebih besar dari penelitian sebelumnya. Hal ini dikarenakan beberapa faktor diantaranya posisi objek penghalang yang terletak tidak lurus di depan sensor. Hal ini dikarenakan gelombang pantul yang disuplai dan ditangkap oleh sensor ultrasonik memiliki sudut tangkap tertentu. Faktor berikutnya yaitu posisi sensor ultrasonik HC-SR04 yang menjorok ke dalam dan diapit antara body atas serta body bawah. Hal tersebut memungkinkan terjadinya gangguan pada proses penerimaan gelombang pantul pada sensor ultrasonik.
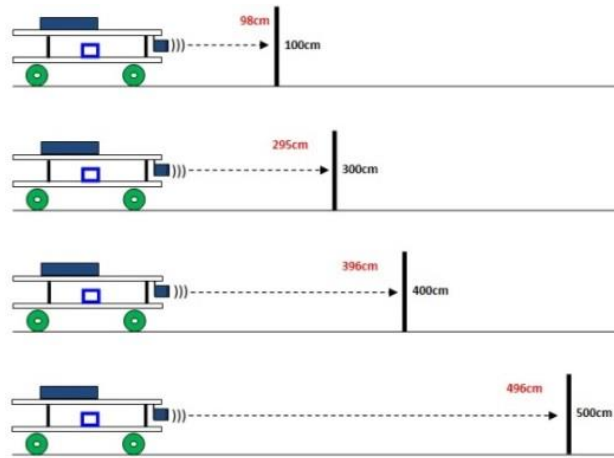

Gambar 7. Penggambaran pengukuran data jarak dengan sensor ultrasonik

Tabel 1. Perbandingan jarak hasil pengukuran

\begin{tabular}{cc}
\hline $\begin{array}{c}\text { Jarak dengan } \\
\text { pengukuran riil (cm) }\end{array}$ & $\begin{array}{c}\text { Jarak dengan } \\
\text { pengukuran sensor } \\
\text { ultrasonik (cm) }\end{array}$ \\
\hline 100 & 98 \\
300 & 295 \\
400 & 396 \\
500 & 496 \\
\hline
\end{tabular}

Wickramasooriya [13] pada tahun 2000 telah melakukan riset untuk mengetahui karakteristik sensor SRF05. Riset tersebut juga menyebutkan tentang pemicu kecepatan tangkap sensor oleh sebuah aplikasi. Namun jarak yang diteliti hanya sampai $33 \mathrm{~cm}$. Zulmi [12] menganalisis rentang jarak sensor HC-SR04 hanya pada $2-30 \mathrm{~cm}$ pada tahun 2014. Secara teori, pengambilan data yang telah dilakukan menunjukkan performa sensor ultrasonik HC-SR04 yang memuaskan. Dikarenakan dapat membaca jarak sampai $500 \mathrm{~cm}$.

Nilai RPM dan kecepatan pada purwarupa yang telah dibuat dapat ditentukan dengan menggunakan rumus 2 sebagai berikut. Dengan keliling roda sebesar $3 \mathrm{~cm}$ dan rpm maksimal pada motor yaitu 6000. Tabel 1 menunjukkan hasil perhitungan RPM.

$$
v=r x \omega
$$

Dimana :

$\begin{array}{ll}\mathrm{v} & : \text { kecepatan linier }(\mathrm{km} / \mathrm{h}) \\ \mathrm{r} & : \text { radius roda }(\mathrm{cm}) \\ \grave{\omega} & : \text { kecepatan anguler }(\mathrm{rpm})\end{array}$ 
Tabel 2. Hasil perhitungan RPM dan kecepatan linier dengan masukan sinyal PWM

\begin{tabular}{ccc}
\hline PWM\% & RPM & $\mathbf{K m} / \mathbf{h}$ \\
\hline $0 \%$ & 0 & $0 \mathrm{~km} / \mathrm{h}$ \\
$64(25 \%)$ & 1500 & $5,6 \mathrm{~km} / \mathrm{h}$ \\
$127(50 \%)$ & 3000 & $11,3 \mathrm{~km} / \mathrm{h}$ \\
$191(75 \%)$ & 4500 & $16,9 \mathrm{~km} / \mathrm{h}$ \\
$255(100 \%)$ & 6000 & $22,6 \mathrm{~km} / \mathrm{h}$ \\
\hline
\end{tabular}

Tahap selanjutnya yaitu penulisan program "Bahasa C" pada mikrokontroler Arduino. Pada tahap penulisan program dan pengujian hanya dimasukan sebagian dari seluruh data program aplikasi untuk mengetahui program data yang sesuai untuk membuat kendaraan berhenti sempurna. Variasi kecepatan dan jarak yang ditentukan menghasilkan empat kombinasi dalam penelitian ini. Kombinasi pertama yaitu pada jarak $100 \mathrm{~cm}$ dengan PWM 64 (25\%). Kombinasi kedua pada jarak $300 \mathrm{~cm}$ dengan PWM 127 (50\%). Jarak $400 \mathrm{~cm}$ dan PWM 191 (75\%) sebagai kombinasi ketiga. Kombinasi terakhir PWM 255 (100\%) pada jarak $500 \mathrm{~cm}$. Program yang dibuat dengan kriteria dua tahap pengurangan PWM. Pengurangan PWM dalam dua tahap dengan waktu milidetik dimaksudkan untuk mensimulasi pengurangan kecepatan secara perlahan, tidak mendadak. Dengan analogi pedal rem yang diinjak oleh pengemudi secara bertahap dan perlahan. Pada gambar 9 menampilkan waktu yang diperlukan purwarupa untuk berhenti sempurna dengan PWM 64 pada jarak $100 \mathrm{~cm}$. Sedangkan gambar 10 menunjukkan karakteristik penurunan PWM pada jarak $300 \mathrm{~cm}$ dengan PWM 127. Waktu yang diperlukan purwarupa untuk berhenti sempurna pada jarak $400 \mathrm{~cm}$ dengan PWM 191 ditunjukkan pada gambar 11. Pada gambar 12 ditampilkan waktu untuk berhenti sempurna bagi purwarupa pada jarak $500 \mathrm{~cm}$ dengan PWM 255 yang diperoleh dari Serial Monitor Arduino.

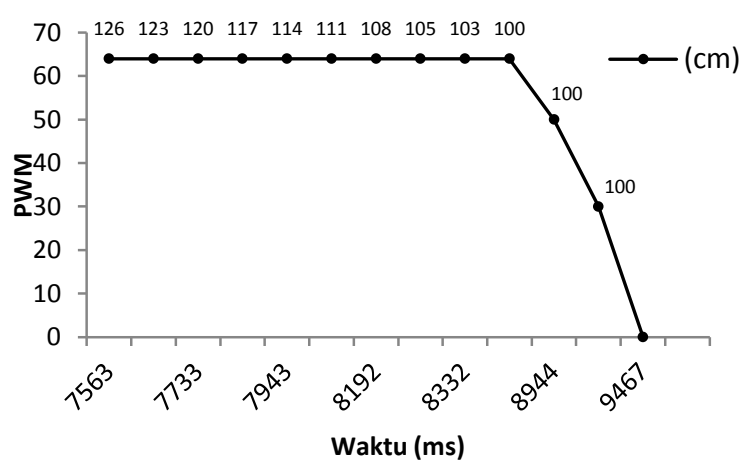

Gambar 8. Waktu yang diperlukan untuk berhenti sempurna pada pwm 64 jarak $100 \mathrm{~cm}$

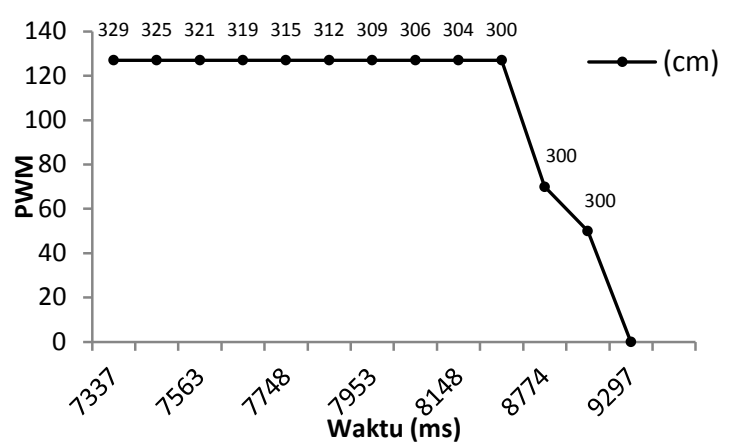

Gambar 9. Waktu yang diperlukan untuk berhenti sempurna pada pwm 127 jarak $300 \mathrm{~cm}$

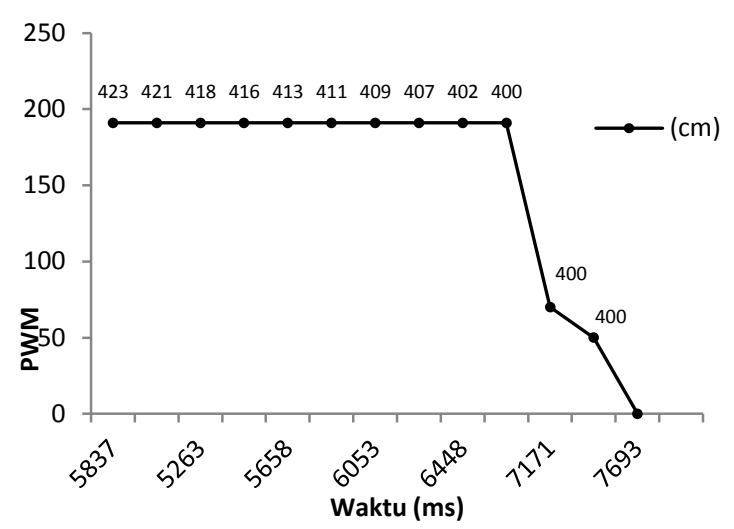

Gambar 10. Waktu yang diperlukan untuk berhenti sempurna pada pwm 191 jarak $400 \mathrm{~cm}$

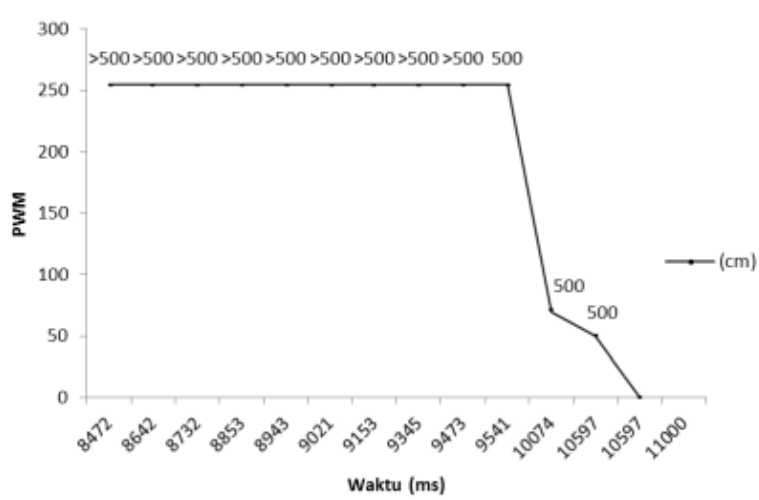

Gambar 11. Waktu yang diperlukan untuk berhenti sempurna pada pwm 255 jarak $500 \mathrm{~cm}$

Pada gambar 8 terlihat adanya penurunan PWM yang terjadi dalam dua tahap yang terjadi saat sensor ultrasonik mendeteksi adanya objek penghalang. Sinyal dari sensor kemudian masuk ke program Arduino dan diproses dengan keluaran berupa dua tahap penurunan PWM. Pada variasi pertama, PWM mula sebesar 64 diturunkan menjadi 50 kemudian 30 dan akhirnya 0 atau berhenti sempurna. Proses penurunan PWM dimulai pada waktu 8.700 milisekon. Pada PWM 127 , penurunan terjadi dimulai pada waktu 8.500 milisekon dengan jenjang PWM 70 dan 50 kemudian berhenti sempurna ditunjukkan pada 
gambar 9. Pada gambar 10 menunjukkan variasi PWM 191 yang mengalami penurunan kecepatan dengan jenjang PWM 70 dan 50, setelah itu baru berhenti sempurna. Proses pengereman dimulai pada 6.900 milisekon. Gambar 11 menunjukkan PWM 255, jenjang penurunan PWM yang terjadi sama nilainya dengan variasi PWM 127 yaitu 70 dan 50 dimulai pada waktu 9.700 milisekon. Waktu pengereman dimulai ketika sensor ultrasonik menerima rangsangan berupa penghalang. Perbandingan waktu mulai pengereman ditampilkan pada tabel 3 .

Tabel 3. Perbandingan Waktu mulai pengereman

\begin{tabular}{ccc}
\hline PWM \% & $\begin{array}{c}\text { Waktu mulai } \\
\text { Pengereman } \\
\text { (milisekon) }\end{array}$ & $\begin{array}{c}\text { Jarak } \\
(\mathbf{c m})\end{array}$ \\
\hline 64 & 8.700 & 100 \\
127 & 8.500 & 300 \\
191 & 6.900 & 400 \\
255 & 9.700 & 500 \\
\hline
\end{tabular}

Dua tahap penurunan PWM yang dilakukan mikrokontroler Arduino membutuhkan waktu 523 ms pada tahap I dan 523 ms pada penurunan tahap II. Apabila dijumlahkan maka penurunan PWM membutuhkan waktu 1 detik setelah sensor mendeteksi adanya objek penghalang dan berhenti sempurna.

Setelah berhenti sempurna, jarak antara purwarupa dan objek penghalang diukur. Dan ternyata terdapat perbedaan nilai jarak dari pengukuran sensor dan jarak yang diukur dengan meteran. Jarak yang tertampil pada pengukuran sensor $100 \mathrm{~cm}$ tetapi pada pengukuran sebenarnya $96 \mathrm{~cm}$. Pada jarak $300 \mathrm{~cm}$ saat diukur kembali dengan meteran terbaca $294 \mathrm{~cm}$. Kemudian jarak $400 \mathrm{~cm}$ pada sensor ultrasonik sebenarnya $395 \mathrm{~cm}$. Dan jarak $500 \mathrm{~cm}$ ketika diukur kembali dengan meteran $492 \mathrm{~cm}$.

Berdasarkan data yang diperoleh diketahui bahwa rangkaian pada purwarupa tidak dapat mengentikan kecepatan secara mendadak. Sistem pengendali kecepatan yang disematkan hanya dapat memutus suplai tegangan ke motor. Saat suplai tegangan diputus, purwarupa masih bergerak dengan gaya sisa yang terjadi. Apabila diaplikasikan pada mobil listrik maka rangkaian sistem pengendali kecepatan ini akan berfungsi layaknya pedal rem yang diinjak secara perlahan. Sistem mulai bekerja saat sensor ultrasonik menangkap adanya objek penghalang yang memantulkan gelombang ultrasonik [14]. Hasil penelitian ini sejalan dengan penelitian Rajeev [15] yang juga menggunakan sensor ultrasonik dan mikrokontroler dalam mengendalikan kecepatan saat pengemudi tidak dapat melakukan pengereman secara manual. Pada Penelitian Shun [16] menyampaikan bahwa gabungan sensor humiditas, detektor intensitas grip, modul hujan dan sensor jarak digunakan untuk membatasi kecepatan atau melakukan pengereman membutuhkan waktu 2,6 detik. Penelitian lanjutan Shun menambah pengendalian PWM pada gabungan sensor tersebut maka waktu yang diperlukan untuk melakukan pengereman sampai berhenti turun sampai 1,49 detik.

\section{Penutup}

Penelitian pengendali kecepatan dengan mikrokontroler Arduino UNO dan sensor ultrasonik HC-SR04 dapat diambil kesimpulan yaitu Rangkaian TX dan RX sensor ultrasonik HCSR04 sudah dalam satu modul sehingga memudahkan dalam pemasangan serta data yang dihasilkan lebih presisi. Pengukuran jarak dapat ditampilkan pada LCD dengan satuan $\mathrm{cm}$.

Penggunaan mikrokontroler Arduino UNO mudah dalam pengaplikasian. Pemrograman Bahasa $\mathrm{C}$ pada mikrokontroler baik baca dan tulis dapat dilakukan berulang kali. Mikrokontroler Arduino responsif dalam membaca sinyal masukan dan mentransfer keluaran baik pada sensor ultrasonik, LCD monitor, dan motor DC.

Rangkaian sistem pengendali kecepatan dapat diaplikasikan pada mobil listrik dengan kriteria penurunan PWM secara perlahan dalam dua tahap. Proses penurunan PWM membutuhkan waktu 1 detik setelah sensor mendeteksi objek penghalang.

Saran untuk penelitian lanjutan dengan sensor ultrasonik HC-SR04 dengan mikrokontroler Arduino UNO yaitu penelitian pada pemrograman Bahasa $\mathrm{C}$ yang mampu melakukan pengereman baik dari pemutusan energi listrik dan alat dikoneksikan dengan pedal rem sehingga kontrol dapat dilakukan secara mekanik dan elektrik. Penelitian lanjutan agar dapat membuat proses pengereman secara lebih responsif.

Penelitian dengan mikrokontroler dan sensor ultrasonik tipe lain kemudian data dibandingkan dengan mikrokontroler Arduino UNO dan sensor ultrasonik HC-SR04.

Penelitian pemrograman Mikrokontroler lanjutan yang bertujuan proses pengereman dengan anti Brake lock system. 


\section{Daftar Pustaka}

[1] H. I. Zainuri, “Analisis Sumber Tenaga Kendaraan pada Mobil Listrik Untuk Mendapatkan Efisien Data," Jakarta, 2015.

[2] N. Trisnaningtyas, A.B dan Sutantra, “Pengembangan Model 'Regenerative Brake' pada Mobil Listrik Untuk Menambah Jarak Tempuh dengan Variasi Kecepatan," Institut Teknologi Sepuluh November, 2012.

[3] D. M. Evans, Braking Distance. Australian Mathematical Sciences Institute.

[4] K. Priyanka and A. Mariyammal, "DC Motor Speed Control Using Matlab,” vol. 3, no. 2, pp. 584-587, 2018.

[5] A. Anggoro, dan Setyo, "Kendali Kecepatan Motor Dc Berdasarkan Perubahan Jarak Menggunakan Pengendali Logika Fuzi Berbasis Mikrokontroler At89c51," Universitas Gajah Mada, 2014.

[6] D. T. Arif and A. Aswardi, "Kendali Kecepatan Motor DC Penguat Terpisah Berbeban Berbasis Arduino," JTEV (Jurnal Tek. Elektro dan Vokasional), vol. 6, no. 2, pp. 33-43, 2020.

[7] S. Reeba Rex and M. S. R. Praba, "A speed control of DC motor with PWM using microcontroller in hardware in loop," Int. J. Eng. Technol., vol. 7, no. 3.27, pp. 116-119, 2018.

[8] S. Arifin and Fathoni, "Pemanfaatan Pulse Widht Modulation Untuk Mengontrol Motor (Studi Kasus Robot Otomatis Dua Deviana," STIMIK Asia
Malang, 2014.

[9] A. Khuamedi, A, dan Soedjarwanto, N, dan Trisanto, "Otomatisasi Pengereman Motor Dc Secara Elektris Sebagai Referensi Sistem Keamanan Mobil Listrik," Electr. - J. Rekayasa Dan Teknol. Elektro, vol. 8, no. 1, pp. 20-30, 2014.

[10] O. O. Adejumo and W. A. Azeez, "Development of a Microcontroller Based DC Motor Speed Control System," World J. Eng. Technol., vol. 07, no. 04, pp. 634-639, 2019.

[11] Z. Hasibuan, Metodologi Penelitian Pada Bidang Ilmu Komputer Dan Teknologi Informasi : Konsep, Teknik, Dan Aplikasi. Jakarta, 2007.

[12] F. Zulmi, "Rancang Bangun Alat Pendeteksi Jarak Aman Pada Kendaraan Berbasis Arduino," Universitas Mercu Buana, Jakarta, 2014.

[13] A. Wickramasooriya, G. Hamilan, L. S. I. L. J. W. M. D. L. W. Wijemanne, and S.R. Munasinghe, "Charasteristics Of Sonar Range Sensor Srf05," University Of Moratua, Srilanka, 2000.

[14] M. Nurhadi, "Perancangan Alat Pengereman Otomatis Pada Mobil Listrik Dengan Sensor Ultrasonik Berbasis Mikrokontroler At89s52," STMIK Nusa Mandiri, 2013.

[15] S. Rajeev, M. Aswin, and T. Koottungal, "PWM Based Automobile Braking System," Int. Res. J. Eng. Technol., vol. 4, no. 4, pp. 2051-2054, 2017.

[16] C. W. Shun and L. C. Yong, "Integrating braking system employing pulse width modulation (PWM) and sensors for speed limiting and braking," AIP Conf. Proc., vol. 2157, no. September, 2019. 